\title{
HUBUNGAN ANTARA MOTIVASI INTRINSIK DAN PROKRASTINASI AKADEMIK DENGAN HASIL BELAJAR PENGURUS HMJ PENDIDIKAN BIOLOGI
}

\author{
Suniaty Burhan \\ Jurusan Pendidikan Biologi Fakultas Tarbiyah dan Keguruan, UIN Alauddin \\ Makassar, Kampus II Jl. H. M. Yasin Limpo No 36 Samata-Gowa, Sulawesi Selatan \\ 92118, Telepon: (0411) 424835, e-mail: suniatyburhan154@ gmail.com

\section{Muh. Rapi} \\ Jurusan Pendidikan Biologi Fakultas Tarbiyah Dan Keguruan, UIN Alauddin \\ Makassar, Kampus II Jl. H. M. Yasin Limpo No 36 Samata-Gowa, Sulawesi Selatan \\ 92118, Telepon: (0411) 424835, e-mail: mrapi@uin-alauddin.ac.id

\section{Umi Kusyairy} \\ Jurusan Pendidikan Islam Anak Usia Dini Fakultas Tarbiyah Dan Keguruan, UIN \\ Alauddin Makassar, Kampus II Jl. H. M. Yasin Limpo No 36 Samata-Gowa, \\ Sulawesi Selatan 92118, Telepon: (0411) 424835, e-mail: syairy_chan@yahoo.com
}

\begin{abstract}
Abstrak
Penelitian kuantitatif ini menggunakan pendekatan korelasional yang bertujuan mengetahui hubungan antara motivasi intrinsik dan prokrastinasi terhadap hasil belajar mahasiswa pengurus HMJ Pendidikan Biologi Universitas Islam Negeri Alauddin Makassar. Penelitian ini terdiri atas tiga variabel yakni dua variabel bebas serta satu variabel terikat. Variabel bebas adalah motivasi intrinsik dan prokrastinasi akademik. Adapun variabel terikat adalah hasil belajar. Penelitian ini memiliki populasi sebanyak 52 orang yang merupakan pengurus HMJ Pendidikan Biologi Angkatan 2017. Penelitian ini memakai instrumen berupa skala motivasi intrinsik, skala prokrastinasi akademik, serta dokumentasi berupa nilai IPS (Indeks Prestasi Semester). Adapun teknik analisis data menggunakan teknik statistik deskriptif dan inferensial. Hasil analisis motivasi intrinsik menunjukkan nilai rata-rata sebesar 47,74 dengan kategori sedang, prokrastinasi akademik menunjukkan nilai rata-rata sebesar 46,63 dengan kategori sedang, dan hasil belajar diperoleh nilai rata-rata sebesar 81,01 berada pada kategori tinggi. Hasil analisis statistik inferensial dengan uji F menunjukkan bahwa nilai $F_{\text {hitung }}>F_{\text {tabel }}(0,297>0,05)$, sehingga Ho ditolak dan Ha diterima yang berarti terdapat hubungan antara motivasi intrinsik dan prokrastinasi akademik dengan hasil belajar mahasiswa pengurus HMJ Pendidikan Biologi Universitas Islam Negeri Alauddin Makassar.
\end{abstract}

Kata Kunci : Motivasi Intrinsik, Prokrastinasi Akademik, Hasil Belajar 


\begin{abstract}
This quantitative research used correlational approaches which aimed to know the correlation between the intrinsic motivation and the procrastination to the cognitive student achievement the members' organization of HMJ Biology Education of Alauddin Makassar State Islamic University (UIN). This research involved three variables: two independent variables, the intrinsic motivation and the academic procrastination and one dependent variable, the student achievement. The population of this study was 52 members of organization of HMJ Biology Education 2017. This study used intrinsic motivation scale instrument, academic procrastination scale and documentation of IPS score as learning achievement (Semester Grade Point Average). The data analysis techniques used the descriptive statistics and the inferential statistics. The result of intrinsic motivation analysis is 47,74 in the medium category, academic procrastination is 46,63 in medium category and learning achievement is 81,01 in the high category. The result of inferential statistic analysis with $F$ tests showed that $F_{\text {count }}>F_{\text {table }}(0,297>0,05)$, which means there was correlation between intrinsic motivation and academic procrastination with the achievement of the students of the members organization of HMJ Biology Education 2017of Alauddin Makassar State Islamic University (UIN).
\end{abstract}

Keywords: Intrinsic Motivation, Academic Procrastination, Student Achievement

\title{
PENDAHULUAN
}

Pendidikan berperan penting terhadap penciptaan masyarakat yang cerdas secara intelektual, spiritual, dan emosional. Pelaksanaan penyelenggaran pendidikan sebaiknya disesuaikan pada tujuan pendidikan nasional. Hal ini tercantum dalam Undang-Undang RI No 20 Tahun 2003 mengenai sistem pendidikan Nasional pada Bab II pasal 3 yakni: pengembangan kemampuan, pembentukan watak dan peradaban bangsa yang bermanfaat untuk mencerdaskan kehidupan bangsa.

Pendidikan adalah proses yang akan berlangsung di sepanjang rentang kehidupan manusia. Pendidikan akan senantiasa melibatkan proses belajar, karena belajar pada dasarnya adalah bagian dari pendidikan. Proses belajar adalah prioritas utama dalam dunia pendidikan. Manusia akan selalu belajar, karena setiap tahapan dalam kehidupannya akan dipertemukan dengan permasalahan yang memerlukan solusi dan tentunya menuntut manusia untuk belajar dalam menghadapinya.

Mahasiswa adalah sumber daya manusia yang penting bagi negara karena mahasiswa adalah generasi muda yang akan memajukan suatu bangsa. Dengan pendidikan, akhlak yang baik dan wawasan yang luas, mahasiswa yang berkualitas akan dapat memberikan kemajuan yang berarti untuk negara. Perguruan tinggi adalah wadah untuk menghasilkan mahasiswa yang berkualitas, karena banyak hal yang dapat diperoleh mahasiswa pada perguruan tinggi, yaitu berupa ilmu pengetahuan, sikap kepemimpinan, pengetahuan dalam bermasyarakat dan berorganisasi. Berorganisasi merupakan salah satu cara mahasiswa memeroleh pengalaman dan pengetahuan di luar pengetahuan akademik. Dengan memiliki pengalaman dan wawasan yang luas akan 
membantu mahasiswa untuk menghadapi kehidupan mendatang setelah menempuh pendidikan formal.

Berorganisasi merupakan kegiatan ekstrakulikuler yang cukup banyak diminati oleh mahasiswa. Cukup banyak mahasiswa yang mengikuti dua atau lebih kegiatan organisasai. Mahasiswa yang aktif pada kegiatan-kegiatan keorganisasian disebut sebagai mahasiswa aktivis. Pada umumnya mahasiswa aktivis memiliki kegitan yang lebih padat karena selain harus kuliah untuk memperoleh pendidikan formal, mahasiswa aktivis juga harus meluangkan waktunya untuk berorganisasi. Dua kegiatan yang digeluti mahasiswa aktivis membuatnya harus pandai mengatur waktu, agar berhasil dalam kegiatan organisasi dan dalam kegiatan akademik.

Fenomena di atas disebabkan karena adanya motivasi intrinsik yang dimiliki mahasiswa aktivis. Motivasi intrinsik yang dimiliki mahasiwa berpengaruh pada pengerjaan tugas-tugas akademik. Motivasi belajar peserta didik dapat mendorong minatnya untuk terus belajar (Nirwan, dkk., 2016: 36). Mahasiwa yang memiliki motivasi intrinsik tinggi kecenderungan prokrastinasinya akan rendah. Senecal, Koestner, serta Vallerand menjelaskan bahwa prokrastinasi akademik merupakan masalah motivasi yang terfokus pada kemampuan mengatur waktu dengan baik daripada sifat kemalasan (Lee, 2015: 5). Motivasi merupakan kondisi yang mendorong individu untuk menjalani aktivitas tertentu agar mencapai tujuan tertentu pula (Suryabrata dalam Djaali, 2007: 101). Hirst mengatakan bahwa motivasi intrinsik merupakan keyakinan individu untuk mengerjakan suatu aktivitas dengan perasaan yang nyaman dan atas dasar keinginan diri sendiri. Dengan adanya keyakinan yang dimiliki mahasiswa aktivis, segala pekerjaan yang dilakukan akan mampu diselesaikan dengan baik (Ghufron dan Risnawita, 2011: 86).

Universitas Islam Negeri Alauddin Makassar adalah salah satu perguruan tinggi yang memiliki banyak mahasiswa aktivitas yang terbentuk dari organisasi-organisasi dilingkungan kampus. Kesibukan mahasiswa aktivis dalam kegiatan organisasi terkadang membuat mahasiswa aktivis sulit untuk membagi waktunya. Masalah yang terkait manajemen waktu ini yang seringkali mengganggu kinerja mahasiswa aktivis. Mahasiswa aktivis yang kurang pandai mengatur waktunya akan mengganggu prestasi akademiknya, bahkan memperlama masa studinya. Sehingga, bagi mahasiswa yang sering melakukan prokrastinasi akademik yang menyebabkan terhambat masa studinya dapat saja mengalami hal tersebut.

Adapun dalil yang berhubungan dengan waktu dan berkaitan dengan Prokrastinasi Akademik yakni Al-Qur'an Surah Al-'Ashr ayat 1-3 (Yayasan Penyelenggara Penerjemah Al-Qur'an, 2005:602):

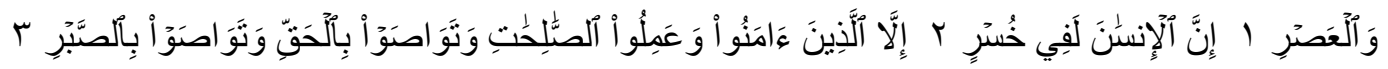

Terjemahannya:

(1) Demi masa, (2) Sesungguhnya manusia itu benar-benar dalam kerugian, (3) Kecuali orang-orang yang beriman dan mengerjakan amal saleh dan nasehat 
menasehati supaya mentaati kebenaran dan nasehat menasehati supaya menetapi kesabaran.

Keberhasilan akademik dan pribadi mahasiswa dapat dipengaruhi oleh prokrastinasi. Jika hal ini berlanjut terus-menerus akan berdampak negatif dalam kegiatan akademik. Prokrastinasi berbeda tiap orang pada umumnya dan berdampak negatif dengan menimbulkan perasaan bersalah, malas, tidak pasti, merasa bodoh atau bahkan kombinasi dari semuanya. Akhirnya, terdapat banyak mahasiswa yang memilih untuk menunda-nunda mengerjakan tugas perkuliahan, menunda belajar untuk ujian akibat sibuk melakukan aktivitas lain yang tidak bermanfaat dalam hal akademik (Djamarah, 2011: 34). Prokrastinasi akademik terjadi karena individu tidak dapat mengatur waktunya dengan baik (Pratiwi, 2010: 25).

Hasil belajar merupakan berbagai perubahan dalam pengetahuan, nilai sikap, keterampilan, dan pemahaman yang sifatnya menetap. Individu dapat mencapai hasil belajar yang baik apabila dapat mengubah tingkah lakunya. Karena jika individu tersebut tidak melakukan perubahan pada perilakunya, maka belum dapat dikatakan sebagai hasil belajar. Perubahan perilaku ini berupa sifat, kebiasaan, keterampilan atau pengetahuan (Siagian, 2009: 131).

Perbedaan hasil belajar diantara peserta didik ternyata dipengaruhi oleh berbagai macam faktor. Sejumlah faktor tersebut dapat berasal dari faktor eksternal dan faktor internal peserta didik. Faktor yang berasal dari kondisi eksternal peserta didik diantaranya adalah keadaan keluarga, keadaan masyarakat, dan keadaan sekolah. Sementara faktor yang berasal dari kondisi internal peserta didik diantaranya adalah tingkat intelegensia, motivasi, minat dan bakat, serta kepribadian peserta didik (Muhibbin, 2001: 133).

Forum Pendidikan Kesejahteraan Keluarga Universitas Pendidikan Indonesia menjelaskan bahwa umumnya mahasiswa yang tergabung dalam organisasi, justeru dapat lulus cepat, karena mereka dapat membagi waktunya dan dapat memanfaatkan waktu yang dilaluinya dengan berbagai kegiatan yang positif. Banyak pula yang semakin bersemangat dan tekun belajar, sehingga tidak terjadi penundaan pada tugasnya. Hal ini menggambarkan citra positif pada mahasiwa aktivis (Dini, 2010: 15). Penjelasan di atas diperkuat oleh hasil penelitian Sentosa bahwasanya pengurus dalam sebuah organisasi kemahasiswaan justru menghasilkan sebuah prestasi yang stabil. Dimana, kesibukan mereka dalam berorganisasi tidak menjadi rintangan, sehingga dapat tetap berkonsentrasi pada kegiatan perkuliahan juga (Dini, 2010: 20).

Berdasarkan beberapa informasi yang telah diuraikan tersebut, maka peneliti kemudian termotivasi untuk melakukan serangkaian penelitian untuk memahami: (1) gambaran motivasi intrinsik pengurus HMJ Pendidikan Biologi Universitas Islam Negeri Alauddin Makassar; (2) gambaran prokrastinasi akademik pengurus HMJ Pendidikan Biologi Universitas Islam Negeri Alauddin Makassar; (3) gambaran hasil belajar pengurus HMJ Pendidikan Biologi Universitas Islam Negeri Alauddin 
Makassar; (4) hubungan antara motivasi instrinsik terhadap hasil belajar pengurus HMJ Pendidikan Biologi Universitas Islam Negeri Alauddin Makassar; (5) hubungan antara prokrastinasi akademik terhadap hasil belajar pengurus HMJ Pendidikan Biologi Universitas Islam Negeri Alauddin Makassar; (6) hubungan antara motivasi intrinsik dan prokrastinasi akademik dengan hasil belajar mata kuliah biologi pengurus HMJ Pendidikan Biologi Universitas Islam Negeri Alauddin Makassar.

Adapun tujuan diadakannya penelitian ini antara lain untuk memahami: (1) gambaran motivasi intrinsik pengurus HMJ Pendidikan Biologi Universitas Islam Negeri Alauddin Makassar; (2) gambaran prokrastinasi akademik pengurus HMJ Pendidikan Biologi Universitas Islam Negeri Alauddin Makassar; (3) gambaran hasil belajar pengurus HMJ Pendidikan Biologi Universitas Islam Negeri Alauddin Makassar; (4) hubungan antara motivasi intrinsik terhadap hasil belajar pengurus HMJ Pendidikan Biologi Universitas Islam Negeri Alauddin Makassar; (5) hubungan prokrastinasi akademik terhadap hasil belajar pengurus HMJ Pendidikan Biologi Universitas Islam Negeri Alauddin Makassar; (6) hubungan antara motivasi intrinsik dan prokrastinasi akademik terhadap hasil belajar pengurus HMJ Pendidikan Biologi Universitas Islam Negeri Alauddin Makassar.

Pada dasarnya, motivasi adalah kondisi pribadi individu yang memacu individu untuk melakukan aktivitas-aktivitas tertentu guna memperoleh suatu tujuan. Motivasi yang terdapat pada individu akan mewujudkan perilaku yang sesuai dengan tujuan untuk mencapai kepuasan (Ghufron dan Risnawita, 2011: 83). Motivasi intrinsik merupakan kenyaman dan ketertarikan saat beraktivitas pada suatu pekerjaan (Elliot, 2009: 235). Hirst menambahkan bahwa motivasi intrinsik merupakan keyakinan individu untuk mengerjakan suatu aktivitas dengan perasaan yang nyaman dan atas dasar keinginan diri sendiri. Dengan adanya keyakinan yang dimiliki mahasiswa aktivis, segala pekerjaan yang dilakukan akan mampu diselesaikan dengan baik (Ghufron dan Risnawita, 2011: 86).

Empat aspek penting dalam motivasi intrinsik, antara lain : (1) Kesenangan, yakni ekspresi individu dalam melakukan aktivitas tanpa adanya keterpaksaan; (2) Ketertarikan, yakni keinginan individu dalam beraktivitas karena menganggap aktivitas tersebut mempunyai daya tarik yang unik; (3) memahami kesanggupan, yakni tingkat kemampuan individu dalam beraktivitas secara benar dan baik yang dipicu oleh kemampuan individu itu sendiri; (4) Kebebasan memilih, yakni individu dapat memilih aktivitas yang dianggap tepat dan sesuai untuk dijalaninya (Ghufron dan Risnawita, 2011: 90). Terdapat enam faktor yang mempengaruhi motivasi intrinsik, terdiri atas : (1) Pengakuan; (2) Pekerjaan itu sendiri; (3) Kemajuan; (4) Prestasi; (5) Tanggung jawab; serta (6) Perkembangan (Ghufron dan Risnawita, 2011: 92-93).

Prokrastinasi adalah istilah yang disematkan untuk kebiasaan dalam menunda pekerjaan. Prokrastinasi ini dilakukan dengan sengaja dan berulang-ulang. Ini diakibatkan oleh kesibukan melakukan aktivitas lain yang sebenarnya tidak diperlukan 
dalam pengerjaan tugas tersebut (Ghufron dan Risnawita, 2011: 155). Prokrastinasi terbagi atas dua karaktristik (Boice dalam Fibrianti, 2009: 25), yaitu: (1) prokrastinasi diartikan sebagai penundaan tugas yang lebih sulit dan penting dibanding tugas yang lebih gampang, lebih cepat diselesaikan sehingga lebih mengurangi kecemasan. (2) prokrastinasi diartikan pula sebagai menunggu hingga waktu yang tepat dalam bertindak. Hal ini dimaksudkan agar memaksimalkan hasil yang diperoleh dan meminimalkan risikonya, jika dibandingkan apabila dilakukan seperti biasa, sesuai waktu yang ditetapkan.

Pengaruh prokrastinasi terhadap kepribadian dan keberhasilan akademik dari mahasiswa akan berdampak negatif dalam kegiatan akademik apabila dilakukan terus menerus. Prokrastinasi berbeda tiap orang pada umumnya dan berdampak negatif dengan menimbulkan perasaan bersalah, malas, tidak pasti, merasa bodoh atau bahkan kombinasi dari semuanya. Pada mahasiswa, prokrastinasi ini berbentuk semisal penundaan untuk mengerjakan tugas perkuliahan atau penundaan belajar untuk menghadapi ujian. Mereka sibuk mengerjakan aktivitas yang tidak berkaitan dengan kegiatan akademik (Dini, 2010: 34).

Pada dasarnya, prokrastinator atau individu yang memiliki kebiasaan prokrastinasi tidak bermaksud untuk bersikap acuh atau menghindari tugas yang dihadapinya. Mereka hanya menunda pengerjaan tugas tersebut, sehingga menghabiskan waktu, tenga dan biaya yang tidak sedikit. Akibatnya, dia sering mengalami kegagalan dalam menyelesaikan tugas tepat waktu (Ghufron dan Risnawita, 2011: 152). Prokrastinasi akademik terjadi karena individu tidak dapat mengatur waktunya dengan baik. Prokrastinator lebih banyak meluangkan waktu bersama teman-teman atau melakukan kegiatan sosial dibanding mengerjakan tugas, sehingga individu hanya meluangkan sedikit waktunya atau cenderung mengabaikan tugas akademik. Selain itu, kelelahan fisik (fatigue) juga merupakan faktor yang menyebabkan terjadinya perilaku prokrastinasi. Individu yang mengalami kelelahan fisik akan cenderung melakukan prokrastinasi yang lebih tinggi untuk daripada yang tidak mengalami kelelahan fisik (Ghufron dan Risnawita, 2011: 164).

Prokrastinasi akademik mempunyai empat ciri yang terdiri atas: (1) Penundaan individu saat memulai atau menyelesaikan tugas yang dihadapi; (2) Keterlambatan pengerjaan tugas; (3) Interval waktu diantara rencana dan kinerja aktual; (4) kesibukan melakukan aktivitas lainnya yang dianggap lebih menyenangkan dibanding melakukan tugas yang seharusnya diselesaikan (Ghufron dan Risnawita, 2011: 158-159).

Prokrastinasi akademik dipengaruhi oleh dua faktor, yaitu: (1) Faktor internal (kepribadian individu, kelelahan fisik, besarnya motivasi yang dimiliki individu, batas waktu, dan manajemen waktu yang kurang); (2) faktor eksternal (pola asuh orangtua, tingkat pendidikan individu, serta keadaan lingkungan) (Ghufron dan Risnawita, 2011: 163-165). 
Adapun hasil belajar merupakan hasil akhir setelah menjalani proses belajar yang nampak pada perubahan perilaku yang mampu diamati dan diukur (Ngatini, 2012: 153). Hasil belajar diperoleh setelah proses pembeljaaraan yang terwujud melalui perubahan diri mahasiswa berupa perubahan reaksi dan sikap mahasiswa secara biologis maupun psikologis. Sehingga, dapat disimpulkan bahwa hasil belajar yang maksimal akan diperoleh mahasiswa setelah melakukan aktivitas belajar yang dievaluasi dengan alat ukur tertentu (Pangando, 2013: 5).

Perbedaan hasil belajar diantara peserta didik ternyata dipengaruhi oleh berbagai macam faktor, baik faktor yang berasal dari luar peserta didik (faktor eksternal) dan faktor yang berasal dari diri peserta didik itu sendiri (faktor internal). Faktor eksternal dari peserta didik diantaranya adalah keadaan keluarga, keadaan masyarakat dan keadaan sekolah. Sementara faktor internal dari peserta didik diantaranya adalah tingkat intelegensi, motivasi, minat dan bakat, serta kepribadian peserta didik (Muhibbin, 2001: 133). Hal serupa juga dikemukakan oleh Sudjana (2005: 22) bahwa terdapat dua faktor yang mempengaruhi hasil belajar, antara lain : (1) Faktor internal (kondisi jasmani, kondisi mental, dan kondisi kelelahan); serta (2) Faktor eksternal (kondisi keluarga, kondisi sekolah atau pendidikan, dan kondisi masyarakat).

Mahasiswa wajib menuntut ilmu, maka sudah sewajarnya orientasi kuliah menjadi prioritas utama dalam aktivitas keseharian mahasiswa. Sayangnya, ditengah kewajiban ini, tidak sedikit mahasiswa yang memilih ikut kegiatan ekstrakulikuler atau organisasi mahasiswaan yang dikenal dengan sebutan aktivis. Sentosa mengemukakan bahwa organisasi kampus sering dikaitkan dengan aktivis. Aktivis seringkali dideskripsikan sebagai sesosok mahasiswa dengan aktivitas organisasi yang tinggi, namun memiliki hasil belajar atau Indeks Prestasi Kumulatif (IPK) yang rendah (Dini, 2010: 200).

Adanya asumsi bahwa seorang aktivis memiliki prerstasi rendah dikarenakan kurangnya motivasi intrinsik yang dimiliki. Motivasi intrinsik didefinisikan oleh Elliot sebagai suatu dorongan pada diri individu yang menjadikan individu merasa nyaman dan senang sehabis menjalani berbagai tugas. Ketika seorang aktivis memiliki motivasi intrinsik dalam mengerjakan tugas kuliah dan organisasinya, maka tidak akan ada tugas yang akan terbengkalai. Tetapi, ketika seorang aktivis hanya memfokuskan pada satu titik saja, maka akan ada penundaan tugas pada titik lain. Penundaan inilah yang terkadang memberikan dampak buruk pada mahasiwa. Dampak yang terjadi bisa berupa lamanya masa studi, terbengkalainya tugas-tugas yang seharusnya dikerjakan dan menimbulkan rasa bersalah. Perilaku menunda ini dikenal dengan istilah prokrastinasi (Elliot, 2009:232).

Satiadarma mengemukakan bahwa prokrastinasi akademik adalah kegagalan menyelesaikan tugas akademis hingga batas waktu terakhir untuk dikumpulkan. Tidak sedikit mahasiswa yang hanya fokus pada kegiatan organisasi dan mengesampingkan tugas-tugas akademik. Terbukti dari adanya beberapa mahasiswa dalam sebuah organisasi yang menunda untuk mengerjakan tugasnya bahkan tidak mengumpulkannya 
sama sekali, sehingga harus mengulang mata kuliah yang telah diprogramkan pada semester sebelumnya. Perilaku penundaan ini membuat tingkat prokrastinasi semakin tinggi (Satiadarma, 2005:167).

Adanya kecenderungan aktivis untuk prokrastinasi dapat dilihat dari beberapa faktor yaitu kelelahan fisik dan kuraneg mengatur waktu. Kelelahan fisik terjadi karena mahasiwa harus mengikuti proses perkuliahan dan kegiatan organisasi. Kepandaian aktivis dalam mengelola waktu juga akan memengaruhi, dimana ketika aktivis tidak mampu untuk mengatur waktunya, maka kecenderungan untuk prokrastinasi semakin tinggi.

Sejumlah pemaparan di atas akan mengarah pada suatu kesimpulan bahwa motivasi intrinsik dapat mempengaruhi perilaku prokrastinasi individu dalam menyelesaikan berbagai tugas-tugas akademik. Ketika seorang aktivis memiliki motivasi intrinsik yang tinggi, maka secara otomatis akan terbentuk perilaku prokrastinasi yang rendah. Hal ini berlaku pula sebaliknya, apabila seorang aktivis memiliki motivasi intrinsik yang rendah, maka secara otomatis akan terbentuk perilaku prokrastinasi yang tinggi.

\section{METODOLOGI PENELITIAN}

Penelitian ini berbentuk penelitian korelasional yaitu penelitian yang dilakukan melalui pengumpulan sejumlah data guna mengetahui atau menentukan apakah terdapat atau tidak terdapat hubungan di antara dua variabel penelitian atau lebih untuk menilai besar tidaknya tingkat hubungan antar kedua variabel atau lebih yang diukur tersebut. Tingkat hubungan yang didapatkan lewat hubungan antara kedua varabel atau lebih tersebut diistilahkan sebagai suatu koefisien korelasi. Pada kenyataannya, meskipun terdapat hubungan antara sejumlah variabel tidak dapat diartikan sebagai variabel yang satu merupakan penyebab dari munculnya variabel lainnya. Adapun lokasi penelitian adalah Fakultas Tarbiyah dan Keguruan Universitas Islam Negeri Alauddin Makassar, khususnya mahasiswa pengurus HMJ Pendidikan Biologi angkatan 2016/2017 dengan jumlah populasi sebanyak 52 orang mahasiswa.

Penelitian ini menggunakan instrumen skala likert dan dokumentasi. Skala likert merupakan metode penskalaan pernyataan sikap dengan penggunaan distribusi respon sebagai dasar penentuan nilai skala. Skala ini menggunakan respon yang dikategorikan atas empat macam kategori jawaban, yaitu sangat sesuai, sesuai, kurang sesuai dan tidak sesuai. Skala ini memiliki dua macam pernyataan yakni pernyataan favourable dan unfavourable. Pernyataan favourable ialah pernyataan yang meliputi hal-hal positif mengenai objek sikap. Pernyataan ini cenderung mendukung terhadap objek sikap yang akan diungkap. Sedangkan pernyataan unfavourable ialah pernyataan yang berisikan segala hal negatif terkait objek sikap atau yang tidak mendukung objek sikap yang akan diungkap. Bentuk skala likert yang digunakan dalam penelitian ini dinamakan skala motivasi intrinsik dan skala prokrastinasi akademik. Selanjutnya, peneliti juga 
menggunakan instrument berupa dokumentasi. Dokumentasi dilakukan dengan pengumpulan berbagai data secara terstruktur atau berdasarkan berbagai bukti dokumen seperti catatan, lembaran administrasi, foto atau rekaman yang berkenaan dengan hal yang sedang diteliti. Dokumentasi pada penelitian ini menggunakan nilai IPS (Indeks Prestasi Semester).

Proses analisis pada data dilakukan dengan menganalisis seluruh data yang didapatkan secara sistematis menggunakan:

1. Teknik analisis statistik deskriptif

Statistik deskriptif merupakan teknik statistik yang dipergunakan untuk menganalisis data melalui pendeskripsian atau menjelaskan data yang telah diperoleh secara apa adanya tanpa disertai tujuan untuk membuat kesimpulan yang dapat berlaku untuk umum ataupun menggeneralisasi (Sugiyono, 2013:29). Beberapa tahapan dalam teknik analisis statistik deskriptif antara lain: (a) menyusun tabel distribusi frekuensi; (b) menghitung rata-rata (mean); (c) menghitung standar deviasi; serta (d) persentase nilai rata-rata.

2. Teknik analisis statistik inferensial

Statistik inferensial merupakan teknik statistik yang melakukan sejumlah pengujian guna keperluan pengujian hipotesis penelitian. Terdapat beberapa tahapan dalam teknik analisis statistik inferensial, antara lain: (a) uji prasyarat, yang terdiri atas: (1) uji normalitas dan (2) uji linearitas; serta (b) analisis korelasi (Sugiyono, 2013:29).

\section{HASIL PENELITIAN DAN PEMBAHASAN}

Pembahasan berdasarkan hasil penelitian melalui uji statistik dari rumusan masalah pada penelitian ini dapat dijabarkan sebagai berikut:

\section{Gambaran Motivasi Intrinsik Pengurus HMJ Pendidikan Biologi Universitas Islam Negeri Alauddin Makassar}

Motivasi intrinsik merupakan keyakinan individu untuk mengerjakan suatu aktivitas dengan perasaan yang nyaman dan atas dasar keinginan diri sendiri. Hasil analisis deskriptif motivasi intrinsik pengurus HMJ Pendidikan Biologi Universitas Islam Negeri Alauddin Makassar tersaji pada tabel 1 sebagai berikut:

Tabel 1. Statistik Deskriptif Motivasi Intrinsik

\begin{tabular}{cc}
\hline Statistik Deksriptif & $\begin{array}{c}\text { Nilai } \\
\text { Statistik }\end{array}$ \\
\hline N (ukuran sampel) & 52 \\
Mean (rata-rata) & 47,75 \\
Standar deviasi & 4,39 \\
Skor Minimum & 40 \\
Skor Maksimum & 59 \\
\hline
\end{tabular}


Berdasarkan tabel 1 diketahui gambaran deskriptif motivasi intrinsik pengurus HMJ Pendidikan Biologi Universitas Islam Negeri Alauddin Makassar dengan nilai skor minimum sebesar 40, skor maskimum sebesar 59 dan skor rata-rata sebesar 47,75. Sedangkan kategori motivasi intrinsik pengurus HMJ disajikan pada tabel 2 berikut ini.

Tabel 2. Kategori Motivasi Intrinsik Pengurus HMJ Pendidikan Biologi Universistas Islam Negeri Alauddin Makassar

\begin{tabular}{rlrrrr}
\hline & Batas Kategori & \multicolumn{1}{c}{ Interval } & Frekuensi & Persentase & Ket. \\
& & & & & \\
\hline $\mathrm{X}<[\mu-1,0 \sigma]$ & $\mathrm{X}<44$ & 34 & 15,3 & Rendah \\
{$[\mu-1,0 \sigma] \leq \mathrm{X}<[\mu+1,0 \sigma]$} & $44 \leq \mathrm{X}<52$ & 10 & 19,1 & Tinggi \\
\hline$\mu+1,0 \sigma] \leq \mathrm{X}$ & $52 \leq \mathrm{X}$ & & 100 & \\
\hline Total & & & & \\
\hline
\end{tabular}

Berdasarkan tabel 2, maka diperoleh gambaran motivasi intrinsik pengurus HMJ Pendidikan Biologi bahwa terdapat 8 orang $(15,3 \%)$ berada dalam kategori rendah, 34 orang $(65,4 \%)$ berada dalam kategori sedang, dan 10 orang $(19,1 \%)$ berada dalam kategori tinggi. Selanjutnya, jika dilihat pada tabel 1, nilai rata-rata yang diperoleh sebesar 47,75 apabila dimasukkan dalam ketiga kategori motivasi intrinsik, maka nilai tersebut berada pada interval 44-51 yaitu tergolong kategori sedang. Maka, dapat disimpulkan bahwa pengurus HMJ Pendidikan Biologi memiliki motivasi intrinsik yang sedang, tidak rendah dan tidak tinggi.

Hal ini sejalan dengan teori dari Munandar yang menyatakan bahwa motivasi merupakan kondisi dimana berbagai kebutuhan akan memacu seseorang untuk melakukan serangkaian aktivitas yang mengarah pada tercapaianya tujuan tertentu (Rangga, 2007:17).

\section{Gambaran Prokrastinasi Akademik Pengurus HMJ Pendidikan Biologi Universitas Islam Negeri Alauddin Makassar}

Prokrastinasi akademik merupakan penundaan secara terus-menerus terhadap aktivitas yang berkaitan dengan kegiatan akademik. Hasil analisis data prokrastinasi akademik pengurus HMJ Pendidikan Biologi Universitas Islam Negeri Alauddin Makassar tersaji pada tabel 3 sebagai berikut:

Tabel 3. Statistik Deskriptif Prokrastinasi Akademik

\begin{tabular}{cc}
\hline $\begin{array}{c}\text { Statistik } \\
\text { Deksriptif }\end{array}$ & $\begin{array}{c}\text { Nilai } \\
\text { Statistik }\end{array}$ \\
\hline $\begin{array}{c}\text { N (ukuran } \\
\text { sampel) } \\
\text { Mean (rata-rata) }\end{array}$ & 52 \\
\end{tabular}




\begin{tabular}{cc}
\hline Standar deviasi & 5,98 \\
Skor Minimum & 32 \\
Skor Maksimum & 59 \\
\hline
\end{tabular}

Berdasarkan tabel 3 diketahui gambaran deskriptif prokrastinasi akademik pengurus HMJ Pendidikan Biologi Universitas Islam Negeri Alauddin Makassar dengan nilai skor minimum sebesar 32, skor maskimum sebesar 59 dan skor rata-rata sebesar 46,63. Sedangkan kategori prokrastinasi akademik pengurus HMJ disajikan pada tabel 4 berikut ini.

Tabel 4. Kategori Prokrastinasi Akademik Pengurus HMJ Pendidikan Biologi Universitas Islam Negeri Alauddin Makassar

\begin{tabular}{clrrl}
\hline Batas Kategori & Interval & Frekuensi & Persentase & Ket. \\
\hline $\mathrm{X}<[\mu-1,0 \sigma]$ & $\mathrm{X}<41$ & 7 & 13,3 & Rendah \\
{$[\mu-1,0 \sigma] \leq \mathrm{X}<[\mu+1,0 \sigma]$} & $41 \leq \mathrm{X}<53$ & 34 & 67,3 & Sedang \\
{$[\mu+1,0 \sigma] \leq \mathrm{X}$} & $53 \leq \mathrm{X}$ & 11 & 19,1 & Tinggi \\
\hline Total & & & 100 & \\
\hline
\end{tabular}

Berdasarkan tabel 4, maka diperoleh gambaran prokrastinasi akademik pengurus HMJ Pendidikan Biologi bahwa sebanyak 7 orang $(13,3 \%)$ berada dalam kategori rendah, 34 orang $(67,3 \%)$ berada dalam kategori sedang dan 11 orang $(19,1 \%)$ berada dalam kategori tinggi. Selanjutnya, mengacu pada tabel 3, nilai rata-rata yang diperoleh sebesar 46,6, apabila dimasukkan dalam ketiga kategori prokrastinasi akademik, maka nilai tersebut berada pada interval 41-52 yaitu dalam kategori sedang. Maka, dapat disimpulkan bahwa pengurus HMJ Pendidikan Biologi memiliki prokrastinasi akademik yang sedang, tidak rendah dan tidak tinggi.

Menurut Silver, individu pelaku prokrastinasi tidak bertujuan untuk menghindari atau bersikap acuh pada tugas yang dihadapinya. Namun, mereka cenderung menunda untuk mengerjakannya sampai saat yang dianggap tepat, sehingga justeru membuang percuma waktu yang dibutuhkan untuk menyelesaikan tugas. Penundaan ini menyebabkannya kegagalan pada proses penyelesaian tugas tepat waktu. Prokrastinasi sejatinya adalah gaya hidup dengan sering menunda segala sesuatu yang tidak bertujuan pasti dan proses penghindaran tugas yang sebaiknya tidak boleh dilakukan. Hal ini terjadi karena munculnya kekhawatiran mengalami kegagalan dan persepsi bahwa semua kegiatan harus dilakukan secara benar. Lama-kelamaan kebiasaan menunda ini akan berubah dan menetap sebagai repons dan dapat dinilai sebagai sifat (trait) atau bagian dari prokrastinasi (Ellis dan Knaus dalam Ghufron dan Risnawita, 2011: 152).

\section{Gambaran Hasil Belajar Pengurus HMJ Pendidikan Biologi Universitas Islam Negeri Alauddin Makassar}


Hasil belajar adalah hasil yang didapatkan oleh mahasiswa setelah melakukan proses pembelajaran yang dapat dinilai melalui alat ukur tertentu. Hasil analisis data hasil belajar pengurus HMJ Pendidikan Biologi Universitas Islam Negeri Alauddin Makassar tersaji pada tabel 5 sebagai berikut:

Tabel 5. Statistik Deskriptif Hasil Belajar

\begin{tabular}{cc}
\hline $\begin{array}{c}\text { Statistik } \\
\text { Deksriptif }\end{array}$ & $\begin{array}{c}\text { Nilai } \\
\text { Statistik }\end{array}$ \\
\hline N (ukuran & 52 \\
sampel) & \\
Mean (rata-rata) & 81,01 \\
Standar deviasi & 15,08 \\
Skor Minimum & 36 \\
Skor Maksimum & 100 \\
\hline
\end{tabular}

Berdasarkan tabel 5 diketahui gambaran hasil belajar pengurus HMJ Pendidikan Biologi Universitas Islam Negeri Alauddin Makassar dengan nilai skor minimum sebesar 36, skor maskimum sebesar 100 dan skor rata-rata sebesar 81,01. Sedangkan kategori hasil belajar pengurus HMJ disajikan pada tabel 6 berikut ini.

Tabel 6. Kategori Skor Hasil Belajar

\begin{tabular}{cccc}
\hline Interval & Jumlah & Persentase & Keterangan \\
\hline $86-100$ & 22 & 42 & Sangat Tinggi \\
$76-85$ & 19 & 36 & Tinggi \\
$66-75$ & 4 & 8 & Cukup \\
$56-65$ & 1 & 2 & Rendah \\
$0-55$ & 6 & 12 & Sangat Rendah \\
\hline
\end{tabular}

Berdasarkan tabel 6, maka diperoleh gambaran hasil belajar pengurus HMJ Pendidikan Biologi bahwa sebanyak 6 orang $(12 \%)$ berada dalam kategori sangat rendah, 1 orang $(2 \%)$ berada dalam kategori rendah, 4 orang $(8 \%)$ berada dalam kategori cukup, 19 orang (36\%) berada dalam kategori tinggi, dan 22 orang (42\%) berada dalam kategori sangat tinggi. Selanjutnya, jika dilihat pada tabel 5, nilai ratarata yang didapatkan sebesar 81,01, apabila dimasukkan dalam ketiga kategori di atas, berada pada interval 76-85 yaitu termasuk kategori tinggi. Maka, dapat dtarik kesimpulan bahwa pengurus HMJ Pendidikan Biologi memiliki hasil belajar yang tinggi.

Hasil belajar secara otomatis akan meningkat jika motivasi untuk belajar juga bertambah. Kuat atau lemahnya motivasi belajar dari individu akan berpengaruh pula pada keberhasilan proses belajarnya. Maka, motivasi belajar harus senantiasa 
diupayakan, khususnya motivasi intrinsik yang berasal dari dalam diri individu. Misalnya dengan selalu berpikiran optimis mengenai masa depan, meskipun akan penuh dengan berbagai tantangan yang harus dihadapi agar dapat meraih cita-cita melalui proses belajar (Djamarah, 2011: 166-167).

\section{Hubungan antara Motivasi Intrinsik dengan Hasil Belajar Pengurus HMJ Pendidikan Biologi Universitas Islam Negeri Alauddin Makassar}

Motivasi adalah satu diantara begitu banyak faktor yang dapat mempengaruhi hasil belajar mahasiswa. Hasil analisis data yang menunjukkan adanya hubungan antara motivasi intrinsik dan hasil belajar pengurus HMJ Pendidikan Biologi Universitas Islam Negeri Alauddin Makassar tersaji pada tabel 7.

Tabel 7. Korelasi antara Motivasi Intrinsik dengan Hasil Belajar Pengurus HMJ Pendidikan Biologi Universitas Islam Negeri Alauddin Makassar

\begin{tabular}{lcl}
\hline \multirow{2}{*}{ Korelasi } & $\begin{array}{c}\text { Koefisien } \\
\text { Korelasi }\end{array}$ & Keterangan \\
\hline $\mathrm{X}_{1} \mathrm{Y}$ & 0,195 & Hubungan positif yang sangat rendah \\
\hline
\end{tabular}

Berdasarkan tabel 7, maka diperoleh data yang menunjukkan bahwa koefisien korelasi antara motivasi intrinsik dengan hasil belajar sebesar 0,195 yang berarti tingkat hubungan positif, namun berada dalam kategori yang sangat rendah. Sebagaimana yang dipaparkan Sugiyono dalam bukunya mengenai pedoman penafsiran koefisien korelasi bahwa apabila interval koefisien berada pada rentang 0,00 - 0,199 berarti tingkat hubungannya sangat rendah (Sugiono, 2013: 186). Hal ini menunjukkan bahwa motivasi intrinsik tetap memberikan kontribusi terhadap hasil belajar mahasiswa pengurus HMJ walaupun masih perlu untuk ditingkatkan lagi.

Hasil penelitian yang diperoleh sesuai dengan teori dari Purwanto yang mengemukakan bahwa salah satu faktor yang turut mempengaruhi hasil belajar peserta didik adalah motivasi intrinsik (Purwanto, 2014: 104). Hasil belajar akan meningkat jika motivasi peserta didik untuk belajar juga bertambah. Semakin kuat atau semakin lemah motivasi belajar individu tentu dapat berpengaruhi pada keberhasilan belajar. Sehingga, motivasi belajar harus diupayakan, khususnya motivasi intrinsik yang berasal dari dalam diri dengan selalu memikirkan masa depan yang cerah walaupun penuh dengan rintangan yang harus dihadapi dalam menggapai cita-cita melalui proses belajar (Djamarah, 2011: 166-167).

Hal ini bersesuaian dengan hasil penelitian Nadia Ayyub yang mengungkapkan bahwanya terdapat hubungan signifikan antara motivasi intrinsik dan hasil belajar. Siswa yang sukses memiliki motivasi intrinsik yang lebih tinggi dibanding siswa yang memiliki hasil belajar yang rendah (Ayyub, 2010: 5-6). Berdasarkan hasil penelitian 
peneliti, didapatkan tingkat hubungan yang berada pada kategori sangat rendah. Hal ini dapat saja disebabkan oleh faktor yang lain, misalnya kepribadian. Sesuai dengan teori dari Purwanto yang mengatakan bahwa salah satu faktor yang dapat mempengaruhi hasil belajar peserta didik adalah kepribadiannya (Purwanto, 2014: 104). Kepribadian merupakan salah satu faktor yang dapat berpengaruh terhadap hasil belajar dari peserta didik. Hal ini didasarkan bahwa pada beberapa orang tertentu, ada yang memiliki sifat tekun, berkemauan keras, dan bertanggung jawab, namun pada beberapa orang lainnya ada pula yang malas, tidak bersemangat dalam aktivitasnya dan cenderung tidak bertanggung jawab. Maka, berdasarkan data yang diperoleh dapat ditarik kesimpulan bahwasanya motivasi intrinsik merupakan salah satu faktor yang dapat mempengaruhi hasil belajar mahasiswa. Namun, masih terdapat banyak faktor lainnya yang turut berpengaruh seperti faktor kepribadian yang belum dikembangkan oleh peneliti.

\section{Hubungan antara Prokrastinasi Akademik dengan Hasil Belajar Pengurus HMJ Pendidikan Biologi Universitas Islam Negeri Alauddin Makassar}

Prokrastinasi akademik merupakan salah satu faktor yang berpengaruh terhadap hasil belajar mahasiswa. Hasil analisis data yang menunjukkan adanya hubungan antara prokrastinasi akademik dengan hasil belajar pengurus HMJ Pendidikan Biologi Universitas Islam Negeri Alauddin Makassar tersaji pada tabel 8.

\section{Tabel 8. Korelasi antara Prokrastinasi Akademik dengan Hasil Belajar Pengurus HMJ Pendidikan Biologi Universitas Islam Negeri Alauddin Makassar

\begin{tabular}{ccc}
\hline Korelasi & Koefisien Korelasi & Keterangan \\
\hline $\mathrm{X}_{2} \mathrm{Y}$ & $-0,199$ & Hubungan negatif yang sangat rendah \\
\hline
\end{tabular}

Berdasarkan tabel 8, maka diperoleh data yang menunjukkan bahwa koefisien korelasi antara prokrastinasi akademik dengan hasil belajar sebesar -0,199 yang berarti tingkat hubungan negatif, namun berada dalam kategori yang sangat rendah. Hal ini sesuai dengan pendapat Sugiyono (2013: 186) bahwa apabila interval koefisien berada pada rentang 0,00 - 0,199 berarti tingkat hubungannya sangat rendah. Sehingga, meskipun prokrastinasi akademik pengurus HMJ berada dalam kategori sedang, namun hasil belajar mereka berada pada kategori yang tinggi.

Hal ini tidak sejalan dengan pendapat Suparno yang mengemukakan bahwa terdapat sejumlah faktor yang menjadi penyebab tidak tercapainya hasil belajar. Salah satunya adalah kesulitan dalam mengelola tugas non akademik, akibatnya waktu belajar tersita sehingga mengganggu ketekunan dalam menyelesaikan dan memenuhi tugastugas akademik. Adanya kecenderungan untuk menunda suatu tugas adalah indikasi dari prokrastinasi atau perilaku menunda (Dini, 2010: 14). Sama halnya dengan Quad yang menjelaskan bahwa prokrastinasi akademik terjadi karena individu tidak dapat mengatur 
waktunya dengan baik. Prokrastinator atau pelaku prokrastinasi lebih banyak meluangkan waktu bersama teman-teman atau melakukan kegiatan sosial dibanding mengerjakan tugas yang lebih penting, sehingga individu hanya meluangkan sedikit waktunya atau cenderung mengabaikan tugas akademik (Pratiwi, 2010: 25).

Sesuai dengan realita yang ada, umumnya mahasiswa yang memasuki organisasi kurang pandai dalam mengelola waktunya, sehingga mengganggu prestasi akademiknya. Namun, hal ini berbanding terbalik pada mahasiswa pengurus HMJ Pendidikan Biologi yang mampu memiliki hasil belajar yang tinggi kendatipun mengalami prokrastinasi akademik. Maka, berdasarkan pembahasan mengenai hasil penelitian peneliti dan sejumlah hasil penelitian yang relevan di atas, kiranya perlu diadakan kajian mendalam mengenai faktor-faktor lain, baik intrinsik maupun ekstrinsik yang dapat berpengaruh terhadap korelasi antara prokrastinasi akademik dan hasil belajar.

\section{Hubungan antara Motivasi Intrinsik dan Prokrastinasi Akademik dengan Hasil Belajar Pengurus HMJ Pendidikan Biologi Universitas Islam Negeri Alauddin Makassar}

Motivasi intrinsik dan prokrastinasi akademik merupakan beberapa faktor yang mempengaruhi hasil belajar. Hasil analisis data yang menunjukkan adanya hubungan antara motivasi intrinsik dan prokrastinasi akademik dengan hasil belajar pengurus HMJ Pendidikan Biologi Universitas Islam Negeri Alauddin Makassar tersaji pada tabel 9.

\section{Tabel 9. Korelasi antara Motivasi Intrinsik dan Prokrastinasi Akademik dengan Hasil Belajar Pengurus HMJ Pendidikan Biologi Universitas Islam Negeri Alauddin Makassar}

\begin{tabular}{cc}
\hline Korelasi & Sig \\
\hline $\mathrm{X}_{1} \mathrm{X}_{2} \mathrm{Y}$ & 0,297 \\
\hline
\end{tabular}

Berdasarkan tabel 9, maka diperoleh nilai hasil analisis dengan menggunakan uji $\mathrm{F}$, dimana $\mathrm{F}_{\text {hitung }}$ lebih besar dari $\mathrm{F}_{\text {tabel }}$ atau 0,297 > 0,05. Maka, dapat disimpulkan bahwa Ho ditolak. Ini berarti terdapat hubungan yang positif dan signifikan antara motivasi intrinsik dan prokrastinasi akademik dengan hasil belajar pengurus HMJ.

Variabel prokrastinasi akademik memiliki hubungan yang paling besar dengan variabel hasil belajar, dimana nilai signifikansinya sebesar 0,195. Kemudian disusul oleh variabel motivasi intrinsik dengan nilai signifikansi sebesar -0,199. Data yang diperoleh pada penelitian ini menunjukkan bahwa meskipun sampel pada penelitian ini memiliki motivasi intrinsik yang sedang, prokrastinasi akademik yang sedang, namun data hasil belajar mereka berada pada kategori tinggi. Ini menunjukkan bahwa walaupun mereka disibukkan dengan segala urusan di dalam organisasi kemahasiswaan, mereka mampu memperoleh hasil belajar yang tinggi. 
Berdasarkan penelitian yang dilakukan oleh Jim Nam Choi, prokrastinasi dibedakan menjadi 2 (dua) yaitu prokrastinasi aktif dan prokrastinasi pasif. Tingginya hasil belajar sampel meskipun tingkat prokrastinasi mereka berada pada level sedang disebabkan karena mereka melakukan prokrastinasi aktif. Mahasiswa yang melakukan prokrastinasi aktif suka bekerja di bawah tekanan, mereka suka dengan tantangan dan merasa termotivasi. Mereka tekun dan dapat menyelesaikan tugasnya menjelang berakhirnya waktu (keadaan terdesak) (Choi, 2005: 247). Dalam buku Jaya Setiabudi yang berjudul "The Power Of Kepepet" mengatakan bahwa jika dalam kondisi terdesak dan tidak diberikan pilihan untuk tidak bisa, akan mengakibatkan manusia berpikir dan mencari jalan agar mampu melakukannya. Kondisi kepepet atau terdesak adalah motivasi terbesar di dunia untuk mendorong agar bergerak (Setiabudi, 2009: 3-4). Maka, dapat disimpulkan bahwa kondisi terdesak justru menyebabkan munculnya kreativitas yang memacu semangat dan kemampuan untuk berjuang dengan mengerahkan segala daya dan tenaga.

Prokrastinasi ini menjadi musuh besar bagi mahasiswa. Harusnya mahasiswa sudah mentradisikan membangun self regulated rearning (belajar berdasar regulasi diri). Damayanti (2015: 60) dalam penelitiannya mengungkapkan bahwa belajar berdasar regulasi diri ini mampu meningkatkan hasil belajar karena mahasiswa tersebut akan lebih terlibat dalam proses belajar, lebih partisipatif dalam belajar dan memiliki motivasi yang tinggi, giat dalam mengerjakan tugas-tugas yang diberikan, dan memiliki rasa ingin tahu yang tinggi.

Pemaparan dari Forum Pendidikan Kesejahteraan Keluarga Universitas Pendidikan Indonesia menjelaskan bahwa justeru mahasiswa yang aktif berorganisasi malah cenderung dapat lulus tepat waktu karena mereka mampu mengelola waktunya dan mampu memanfaatkan waktu yang dilaluinya dengan berbagai aktifitas positif. Mereka umumnya termotivasi semangatnya dan semakin rajin dalam proses pembelajaran, sehingga tidak terjadi penundaan pada tugas-tugasnya. Hal ini menggambarkan citra positif pada mahasiwa aktivis. Penjelasan di atas diperkuat oleh hasil penelitian Sentosa yakni aktivis mahasiswa yang aktif sebagai pengurus organisasi kemahasiswaan justeru mampu menghasilkan prestasi yang stabil, artinya kesibukan mereka dalam berorganisasi tidak menjadi hambatan dalam memprioritaskan perkuliahannya (Dini, 2010: 20).

Peneliti akhirnya menyimpulkan berdasarkan sejumlah data yang diperoleh bahwasanya motivasi intrinsik dan prokrastinasi akademik merupakan salah satu faktor yang mempengaruhi hasil belajar mahasiswa. Akan tetapi, masih terdapat faktor lainnya yang dapat berpengaruh pada hasil belajar mahasiswa, misalnya faktor psikologis, faktor lingkungan, dan faktor-faktor lainnya yang masih perlu dikembangkan oleh peneliti. 


\section{KESIMPULAN}

Sejumlah pemaparan hasil penelitian dan pembahasan di atas dapat disimpulkan secara singkat sebagai berikut: (1) Motivasi intrinsik pengurus HMJ Pendidikan Biologi diketahui bahwa 8 orang $(15,3 \%)$ berada dalam kategori rendah, 34 orang $(65,4 \%)$ berada dalam kategori sedang dan10 orang $(19,1 \%)$ berada dalam kategori tinggi. Jika dilihat dari nilai rata-rata yang diperoleh sebesar 47,75 apabila dimasukkan dalam ketiga kategori motivasi intrinsik maka nilai tersebut berada pada interval 44-51 yaitu dalam kategori sedang. (2) Prokrastinasi akademik pengurus HMJ Pendidikan Biologi diketahui bahwa 7 orang $(13,3 \%)$ berada dalam kategori rendah, 34 orang $(67,3 \%)$ berada dalam kategori sedang dan 11 orang $(19,1 \%)$ berada dalam kategori tinggi. Jika dilihat dari nilai rata-rata yang diperoleh sebesar 46,63 apabila dimasukkan dalam ketiga kategori motivasi intrinsik maka nilai tersebut berada pada interval 41-52 yaitu dalam kategori sedang. (3) Hasil belajar pengurus HMJ Pendidikan Biologi diketahui bahwa 6 orang (12\%) berada dalam kategori sangat rendah, 1 orang $(2 \%)$ berada dalam rendah, 4 orang $(8 \%)$ berada dalam kategori cukup, 19 orang $(36 \%)$ berada dalam kategori tinggi dan 22 orang $(42 \%)$ berada dalam kategori sangat tinggi. Nilai rata-rata yang diperoleh sebesar 81,01 apabila dimasukkan dalam ketiga kategori di atas, berada pada interval 76-85 yaitu dalam kategori tinggi. (4) Hasil analisis statistik inferensial ada hubungan motivasi intrinsik dengan hasil belajar pengurus HMJ pendidikan biologi. Penelitian ini memperoleh data yang menunjukkan bahwa koefisien korelasi antara motivasi intrinsik dan hasil belajar sebesar 0,195 yang berarti tingkat hubungan positif, namun berada dalam kategori yang sangat rendah. (5) Hasil analisis statistik inferensial ada hubungan prokrastinasi akademik dengan hasil belajar pengurus HMJ pendidikan biologi. Data penelitian menunjukkan bahwa koefisien korelasi antara prokrastinasi akademik dan hasil belajar sebesar -0,199 yang berarti tingkat korelasi antara prokrastinasi akademik dengan hasil belajar berada dalam kategori hubungan negatif sangat rendah. (6) Berdasarkan perhitungan uji signifikansi dengan menggunakan uji $\mathrm{F}$, diperoleh $F_{\text {hitung }}$ lebih besar dari $F_{\text {tabel }}$ atau 0,297 > 0,05. Maka, dapat disimpulkan bahwa Ho ditolak, artinya terdapat hubungan positif yang signifikan antara motivasi intrinsik dan prokrastinasi akademik dengan hasil belajar pengurus HMJ Pendidikan Biologi Universitas Islam Negeri Alauddin Makassar.

\section{DAFTAR PUSTAKA}

Ayyub, N. (2010). Effect of Intrinsic and Extrinsic Motivation on Academic Performance. (http:www.researchgate.net/publication/25571285, diakses 10 November 2017).

Choi, J.N. (2005). Rethinking Procrastination: Positive Effects of "Active" Procrastination Behavior on Attitudes and Performance. The Journal of Social Psychology. 145 (1), 242-250. 
Dini, A. (2010). Perbedaan Prokrastinasi Akademik antara Mahasiswa yang Aktif dengan yang Tidak Aktif dalam Organisasi Kemahasiswaan PEMA USU.. Medan: Skripsi Universitas Sumatera Utara.

Damayanti, Eka. (2015). Peran Belajar Berdasar Regulasi Diri dan Penyesuaian Diri terhadap Prestasi Belajar Siswi Madrasah Tsanawiyah Muallimat Yogyakarta. Jurnal Biotek (online), Vol 3 No 2 (http://journal.uinalauddin.ac.id/index.php/biotek/article/view/1023, diakses 1 November 2017).

Djaali, H. (2007). Psikologi Pendidikan. Cet. II; Jakarta: PT. Bumi Aksara.

Djamarah, S.B. (2011). Psikologi Belajar. Jakarta: Rineka Cipta.

Elliot, A.J. (2009). Competence Valuation As a Strategic Intrinsic Motivation Process, Journal of Personality and Social Psyhology. 26 (7), 232-242.

Fibrianti, I.D. (2009). Hubungan antara Dukungan Sosial Orang Tua dengan Prokrastinasi Akademik dalam Menyelesaikan Skripsi pada Mahasiwsa Fakultas Psikologi Universitas Diponegoro. (Online). (http://eprints.undip.ac.id/10517/ 1/SKRIPSI.pdf, diakses 02 Juli 2016.

Ghufron, M N. dan Risnawita, R. (2011). Teori-teori Psikologi. Jogjakarta: AR-Ruzz Media.

Lee, E. (2015). The Relationship of Motivation and Flow Experience to Academic Procrastination in University Students. (http://proquest.umi.com, diakses 2 Juni 2016).

Muhibbin, S. (2001). Psikologi Pendidikan dengan Pendekatan Baru. Bandung: Remaja Rosdakarya.

Ngatini. (2012). Peningkatan Keaktifan Dan Hasil Belajar Matematika Tentang Fungsi Melalui Model Pembelajaran Numbered Heads Together Bagi Siswa SMP. Jurnal Manajemen Pendidikan. 7 (2), 150-160.

Nirwan, T.S., Rapi, M., \& Muchlisah. (2016). Hubungan antara Kesiapan Mental dengan Motivasi Belajar pada Mata Pelajaran Biologi. Jurnal Biotek (Online), Vol. 4, No. 2 (http://journal.uin-alauddin.ac.id/index.php/biotek/article/view/ 1886/1826, diakses 10 April 2017).

Pangando, N. (2013). Penerapan Model Pembelajaran Kooperatif Tipe Student Teams Achievement Divisions Untuk Meningkatkan Hasil Belajar Pada Mata Pelajaran IPA Di Kelas IV SDN 1 Tumora. Jurnal Gorontalo. 20 (1), 1-15.

Pratiwi, N.Y. (2010). Hubungan antara Ketakutan Gagal dengan Prokrastinasi Akademik yang Memprogram Skripsi di Fakultas Psikologi Universitas Negeri Makassar. Makassar: Skripsi Fakultas Psikologi Universitas Negeri Makassar.

Purwanto, M., N. (2014). Psikologi Pendidikan. Jakarta: PT. Remaja Rosdakarya.

Rangga, M. (2007). Pengaruh Motivasi Diri terhadap Kinerja Belajar Mahasiswa. (Online). (http://jurnal.upi.edu/abmas/view/432/Pengaruh-motivasi-diri-terhadapkinerja-belajar-mahasiswa-studi-kasus-pada-mahasiswa-universitas-paramadina.html, diakses 30 Oktober 2016). 
Satiadarma, M.P. (2005). Self-Handicapping dan Prokrastinasi dalam Dunia Pendidikan. Journal Provitae. 2 (2), 165-175.

Setiabudi, J. (2009). The Power Of Kepepet. Jakarta: PT. Gramedia Pustaka Utama.

Siagian, R. E., F. (2009). Pengaruh Sikap Mahasiswa Pada Matematik Dan Konsep Diri Terhadap Hasil Belajar Mata Kuliah Pengantar Dasar Matematika. Jurnal Formatif. 1(2), 130-146.

Sudjana. (2005). Metode Statistika. Bandung: Tarsito.

Sugiyono. (2013). Metode Penelitian Pendidikan (Pendekatan Kuantitatif, Kualitatif, dan $R \& D)$. Bandung: Alfabeta.

Yayasan Penyelenggara Penerjemah Al-Qur'an. 2005. Mushaf Al-Qur'an Terjemah. Depok: Al Huda Kelompok Gema Insani. 